\title{
Impact of urbanization on flood of Shigu creek in Dongguan city
}

\author{
Luying Pan, Yangbo Chen, and Tao Zhang \\ Department of Water Resources and Environment, Sun Yat-sen University, Guangzhou, 510275, China \\ Correspondence: Yangbo Chen (eescyb@mail.sysu.edu.cn)
}

Received: 22 November 2017 - Revised: 11 January 2018 - Accepted: 19 January 2018 - Published: 5 June 2018

\begin{abstract}
Shigu creek is a highly urbanized small watershed in Dongguan City. Due to rapid urbanization, quick flood response has been observed, which posted great threat to the flood security of Dongguan City. To evaluate the impact of urbanization on the flood changes of Shigu creek is very important for the flood mitigation of Shigu creek, which will provide insight for flood planners and managers for if to build a larger flood mitigation system. In this paper, the Land cover/use changes of Shigu creek from 1987-2015 induced by urbanization was first extracted from a local database, then, the Liuxihe model, a physically based distributed hydrological model, is employed to simulate the flood processes impacted by urbanization. Precipitation of 3 storms was used for flood processes simulation. The results show that the runoff coefficient and peak flow have increased sharply.
\end{abstract}

\section{Introduction}

Flooding is the natural disaster that has caused the most damages to the world. The Pearl River Delta Area (PRDA) in southern China is in the monsoon area, where heavy storms in the summer are observed very often, and flooding is the most frequent natural disaster threatening the safety of the local society. For the past decades, PRDA has experienced rapid urbanization, and caused significant changes of land use/cover (LUC). Urban land area increased sharply and has become the major or even the dominant land use type, thus speeding up the flood responses, i.e., the increased flood peak flow, and the decreased runoff routing time. This, in one side, strengthens the flood quantities, while on the other side, as more and more people move and live and work in the urban area, flood damages increased largely with urbanization. Dongguan City is one of the newly developed international metropolitans in PRDA in the past three decades, but the flood mitigation measurements were not built to catch up with the flood changes due to rapid urbanization. Purpose of this study is to evaluate the impact of urbanization (LUC change) on flood peak flow and flood runoff coefficient on the typical watershed, the Shigu creek, so to provide scientific base for smart flood measurement planning and building in Dongguan City.
Watershed hydrological model is the tool for watershed flood process simulation in evaluating the impact of LUC change on flooding. Early hydrological model used for flood simulation/prediction is the so called lumped model, such as the SCS model (USDA, 1972), and the Xinanjiang model (Zhao, 1977). Lumped model calibrates model parameters with the observed hydrological data series, for this reason it could not be used in data spare watershed, i. e., in the watersheds with rapid urbanization. Distributed hydrological model is the further development of hydrological model under the big data era. With the development of satellite remote sensing, large quantities of the watershed terrain data was prepared and could be used for hydrological model setting up, thus providing opportunity for distributed hydrological model. Many distributed hydrological models have been proposed, such as the SHE model (Abbott et al., 1986), and the VIC model (Liang et al., 1994).

In this study, the Liuxihe model (Chen et al., 2010), a physically based distributed hydrological model is employed to simulate the flood processes of Shigu creek in Dongguan City, which is a highly urbanized small watershed that is also a very typical watershed in Dongguan City. 


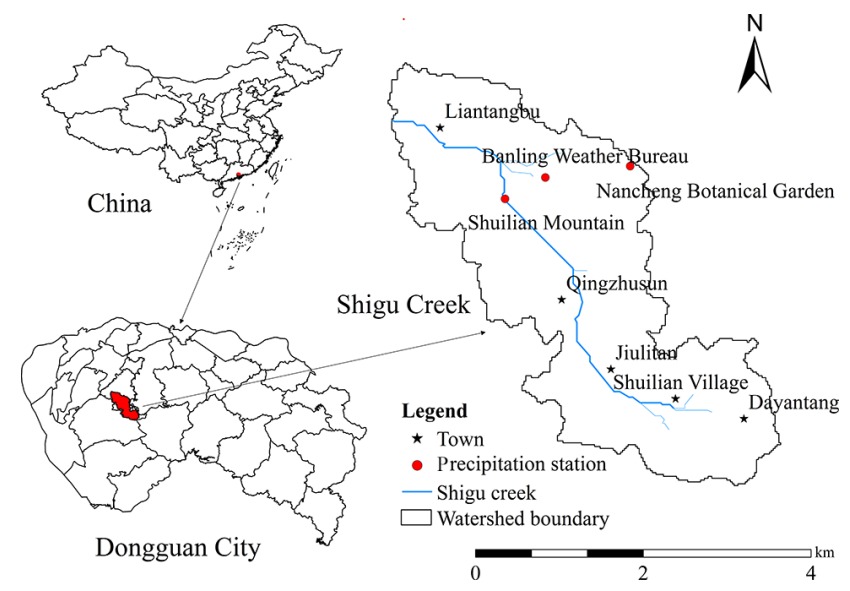

Figure 1. Sketch map of Shigu creek.

\section{Shigu creek and data}

\subsection{Shigu creek}

Shigu creek locates in the south of Dongguan City center, it originates from the south peak of Shuilian mountain, and is the first order branch of Dongjiang River. Shigu creek is a small watershed in Dongguan City, previously it is a watershed in the suburb area of Dongguan City center, but with the rapid urbanization of Dongguan City in the past three decades, Shigu creek becomes a part of Dongguan City. The drainage area of Shigu creek is $19.29 \mathrm{~km}^{2}$, and the length is $11.87 \mathrm{~km}$. Climate in the creek is belong to subtropical marine climate with an annual average temperature of $23.6^{\circ}$, and an annual average precipitation of $1769.5 \mathrm{~mm}$. Heavy storms in the summer monsoon season usually induces serious flood which is a great threat to the security of the downtown area of Dongguan City. Rapid urbanization in the creek makes flooding worse. Figure 1 is a sketch map of Shigu creek, and shows its location in China.

\subsection{Terrain property data}

Terrain property data used for Liuxihe model structure setting up and parameter deriving are DEM, soil type and land use/cover (LUC) type. In this study, the DEM was downloaded from the Shuttle Radar Topography Mission database website at http://srtm.csi.cgiar.org, its spatial resolution is at $30 \mathrm{~m} \times 30 \mathrm{~m}$, as shown in Fig. 2a. From the result it has been found that the highest elevation in the watershed is $368 \mathrm{~m}$, the lowest elevation is $0 \mathrm{~m}$, and the average elevation is $40.94 \mathrm{~m}$.

The soil type was downloaded from FAO soil type dataset at http://www.isric.org, the spatial resolution is $1000 \mathrm{~m} \times 1000 \mathrm{~m}$, as shown in Fig. 2b. There are only two soil types, including Ferric acrisols and Cululic anthrosols, accounting for $83.23,16.77 \%$ of the total watershed area respectively.
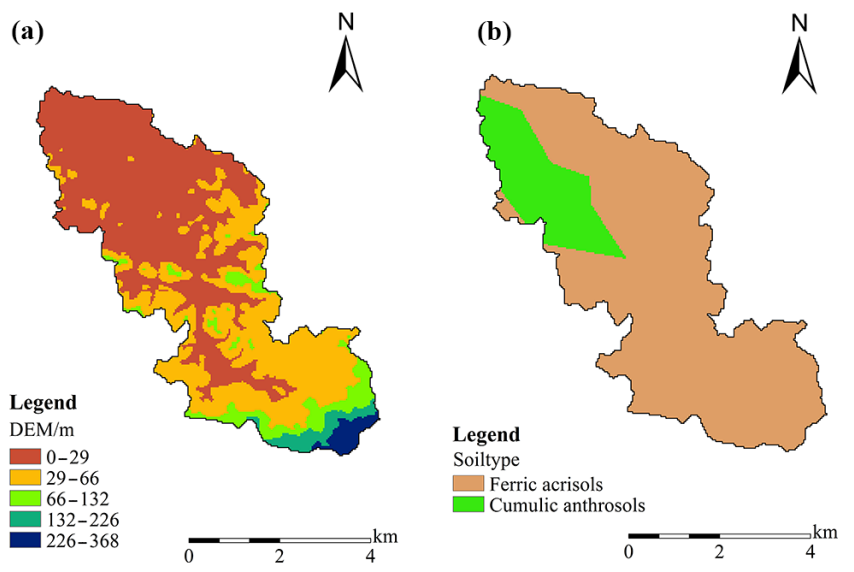

Figure 2. (a) DEM. (b) Soil type. DEM and soil type of Shigu creek.

Due to the rapid urbanization, the LUC type in Shigu creek is in constant changing. Chen et al. (2017a) prepared a LUC dataset for the whole Dongguan City at 12 date from 1987 to 2015 by using the Landsat series satellite imageries, and the SVM algorithm is employed to estimate the LUCs. Spatial resolution of this dataset is at $30 \mathrm{~m} \times 30 \mathrm{~m}$. Figure 3 shows the LUCs of Shigu creek extracted from this dataset from 1987 to 2015 respectively. From the results of Fig. 3, it could be found that the LUC types have not changed. There are 6 LUC types, including forestry land, grass land, farm land, urban land, water body and bare land. But the rates of the LUCs have changed drastically from 1987 to 2015, particularly the urban land area increased rapidly, while the grass land decreased significantly.

\subsection{Hydrological data}

In the Shigu creek, there is no river discharge observation, but there are three rain gauges installed in recent years, and only one rain gauge data is available, so it is a hydrological data spare watershed. For this reason, model parameters could not be optimized, and can only be derived directly from the terrain properties. In this study, precipitation of 3 storms was collected at half hour interval, which will be used as the input to the hydrological model for flood simulation.

\section{Liuxihe Model and parameter}

\subsection{Introduction of Liuxihe model}

Liuxihe Model (Chen, 2009; Chen et al., 2010) is a physically based distributed hydrological model proposed for watershed flood forecasting. In Liuxihe model, the studied watershed is divided into grids horizontally by using the DEM, and are treated as a uniform watershed. Every grid has its own elevation, LUC type and soil type, and is categorized as one of the 3 types, namely hill slope cell, river channel cell 
1987

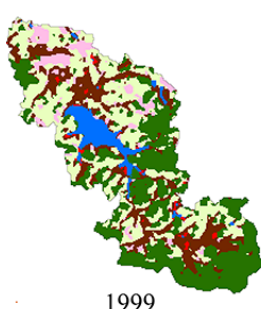

1999

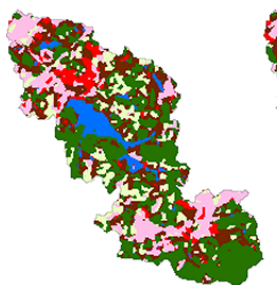

2008
1990

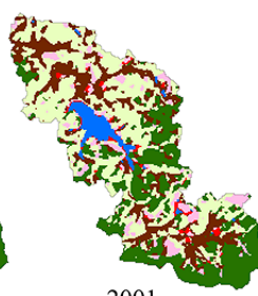

2001

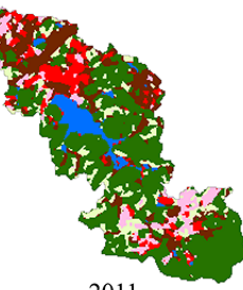

2011

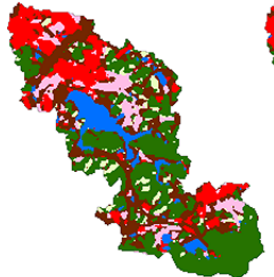

Landuse

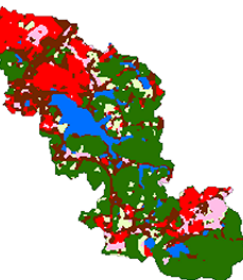

Forestry land
Urban land
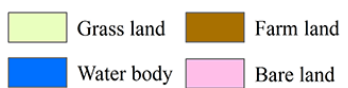

1993

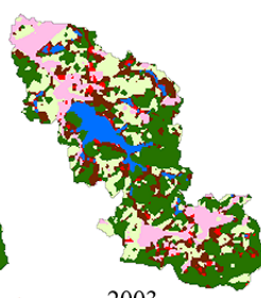

2003

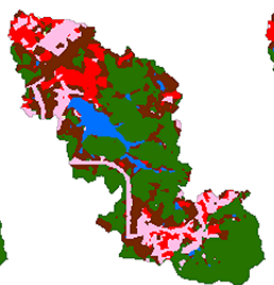

2013
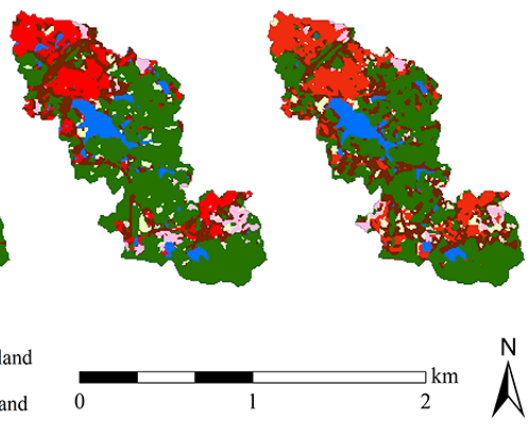

Figure 3. Land use/cover from 1987 to 2015 of Shigu creek.

and reservoir cell. The grid is divided into canopy layer, soil layer and underground layer vertically. Precipitation in every cell is unique and different from other cells, and the model parameters are also considered different in different cells. Evapotranspiration is calculated at cell scale, so does the runoff production. Runoff is categorized as surface runoff, subsurface runoff and underground runoff. Surface runoff produced on the hill slope first, and is routed through the hill slope to its adjacent river cell using the kinematical wave approximation method. Runoff routing in the river channel is treated as river flow routing, and calculated by using the one dimensional diffusive wave approximation method.

The parameters of Liuxihe model are categorized as climate-related parameters, topography-related parameters, soil-related parameters and LUC-related parameters. All parameters are derived directly from their related terrain properties, this makes it be used in hydrological data spare watershed. If there is hydrological data observation, Liuxihe model can optimize model parameters by using PSO algorithm automatically (Chen et al., 2016).

Standard software has been developed for Liuxihe model set up, parameter optimization and flood forecasting (Chen and Dong, 2013), which has several independent software components, including Evapotranspiration Modular, Runoff Production Modular, Runoff Routing Modular and Parameter
Deriving Modular. A public computer infrastructure for implementing Liuxihe model has been built which utilizes big data, parallel computing and supercomputing technologies.

Liuxihe model has been widely used in China for small and medium sized watershed flood forecasting (Liao et al., 2012; Chen et al.,2013), reservoir inflow flood forecasting (Chen et al., 2010; Huang et al., 2017), and large scale watershed flood forecasting (Chen et al., 2017b; Li et al., 2017), and experiences have been accumulated in the past application.

\subsection{Structure set up of Liuxihe model}

The watershed is divided into cells with the collected DEM in this study, the model spatial resolution is set to be $30 \mathrm{~m} \times 30 \mathrm{~m}$. There are 21434 cells in total, which is further categorized as 21106 hill slope cells and 328 river channel cells, no reservoir cell is included. The river channel system is divided into 2 orders, and 13 virtual sections have been prepared after setting 8 nodes. The cross-section sizes of the virtual sections have been estimated by referencing to satellite remote sensing imageries. The Liuxihe model structure is shown in Fig. 4. 


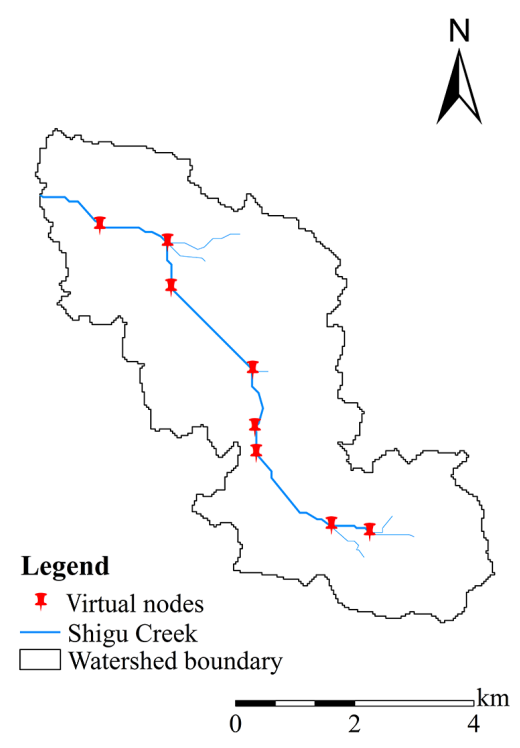

Figure 4. Liuxihe model structure in Shigu creek. (a)

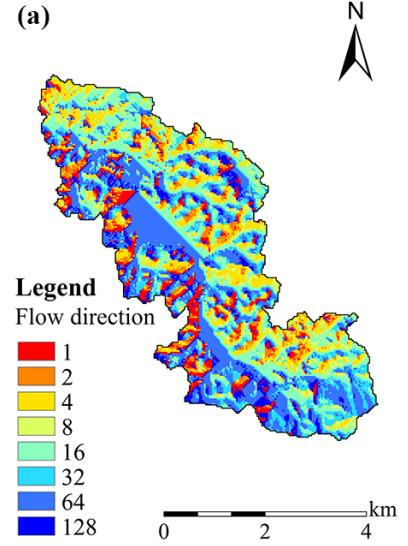

(b)

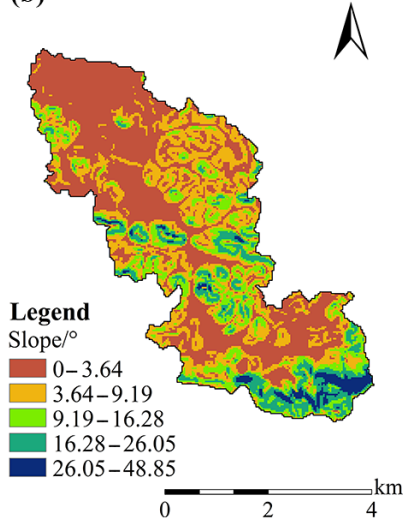

Figure 5. (a) Flow direction. (b) Slope. Topography-related model parameters.

\subsection{Parameterization of Liuxihe model}

Topography-related model parameters are flow direction and slope, these two parameters are derived from the topography data and are not adjusted. In this study, flow direction and slope are derived by using D8 method (Jenson and Dominggue, 1988; Strahler, 1957) based on the DEM. The derived flow direction and slope of Shigu creek are shown in Fig. 5.

Climate-related parameter is evaporation capacity, it is estimated as $5 \mathrm{~mm} \mathrm{day}^{-1}$ for every cells based on local experiences and Liuxihe model parameterization practice. LUCrelated parameters are evaporation coefficient and roughness. According to the past experiences of Liuxihe model parameterization (Chen et al., 2010), evaporation coefficients for all cells are set to 0.7 , and the roughness of forestry land, grass land, farm land, urban land, water body and bare land are proposed as $0.55,0.18,0.36,0.01,0.06$ and 0.12 .
Table 1. Runoff coefficients of the 3 storms. The 3 storms were collected on 7 May 2010, 26 July 2010 and 28 May 2016 respectively. In this paper, they were written as 20100507, 20100726 and 20160528 respectively.

\begin{tabular}{rrrrr}
\hline Time & $\begin{array}{r}\text { Urbanization } \\
\text { Rate }(\%)\end{array}$ & 20160528 & 20100507 & 20100726 \\
\hline 1987 & 1.0 & 0.461 & 0.625 & 0.595 \\
1990 & 1.8 & 0.458 & 0.622 & 0.594 \\
1993 & 2.6 & 0.489 & 0.645 & 0.619 \\
1996 & 3.4 & 0.490 & 0.647 & 0.620 \\
1999 & 5.7 & 0.501 & 0.657 & 0.633 \\
2001 & 8.7 & 0.518 & 0.670 & 0.645 \\
2003 & 10.6 & 0.536 & 0.684 & 0.660 \\
2005 & 10.8 & 0.544 & 0.691 & 0.668 \\
2008 & 15.9 & 0.602 & 0.734 & 0.715 \\
2011 & 17.4 & 0.613 & 0.744 & 0.724 \\
2013 & 16.8 & 0.595 & 0.731 & 0.712 \\
2015 & 20.2 & 0.616 & 0.745 & 0.725 \\
\hline
\end{tabular}

Table 2. Peak Flows of the 3 storms $\left(\mathrm{m}^{3} \mathrm{~s}^{-1}\right)$.

\begin{tabular}{rrrrr}
\hline Time & $\begin{array}{r}\text { Urbanization } \\
\text { Rate }(\%)\end{array}$ & 20160528 & 20100507 & 20100726 \\
\hline 1987 & 1.0 & 23.99 & 68.07 & 82.35 \\
1990 & 1.8 & 23.34 & 67.82 & 80.39 \\
1993 & 2.6 & 28.33 & 72.22 & 89.97 \\
1996 & 3.4 & 31.00 & 73.33 & 96.23 \\
1999 & 5.7 & 34.48 & 73.79 & 92.34 \\
2001 & 8.7 & 29.89 & 72.47 & 90.60 \\
2003 & 10.6 & 30.61 & 76.47 & 91.33 \\
2005 & 10.8 & 32.79 & 78.74 & 99.79 \\
2008 & 15.9 & 42.03 & 87.30 & 106.37 \\
2011 & 17.4 & 40.92 & 86.82 & 105.60 \\
2013 & 16.8 & 37.65 & 83.97 & 99.47 \\
2015 & 20.2 & 41.08 & 86.13 & 105.61 \\
\hline
\end{tabular}

The soil-related parameters are soil water content at saturated condition, field condition and wilting condition, the soil layer thickness, the soil hydraulic conductivity at saturation and the soil characteristics coefficient. According to local experiences, the soil characteristics coefficient takes 2.5, and the soil layer thickness of Ferric acrisols and Cululic anthrosols are set to 850 and $1000 \mathrm{~mm}$ respectively. The soil water content at saturation condition and field condition, and the hydraulic conductivity at saturation condition are determined by the Soil Water Characteristics Hydraulic Properties Calculator (Arya and Paris, 1981), and the soil water content at wilting condition is estimated as $30 \%$ of the soil water content at saturated condition. 


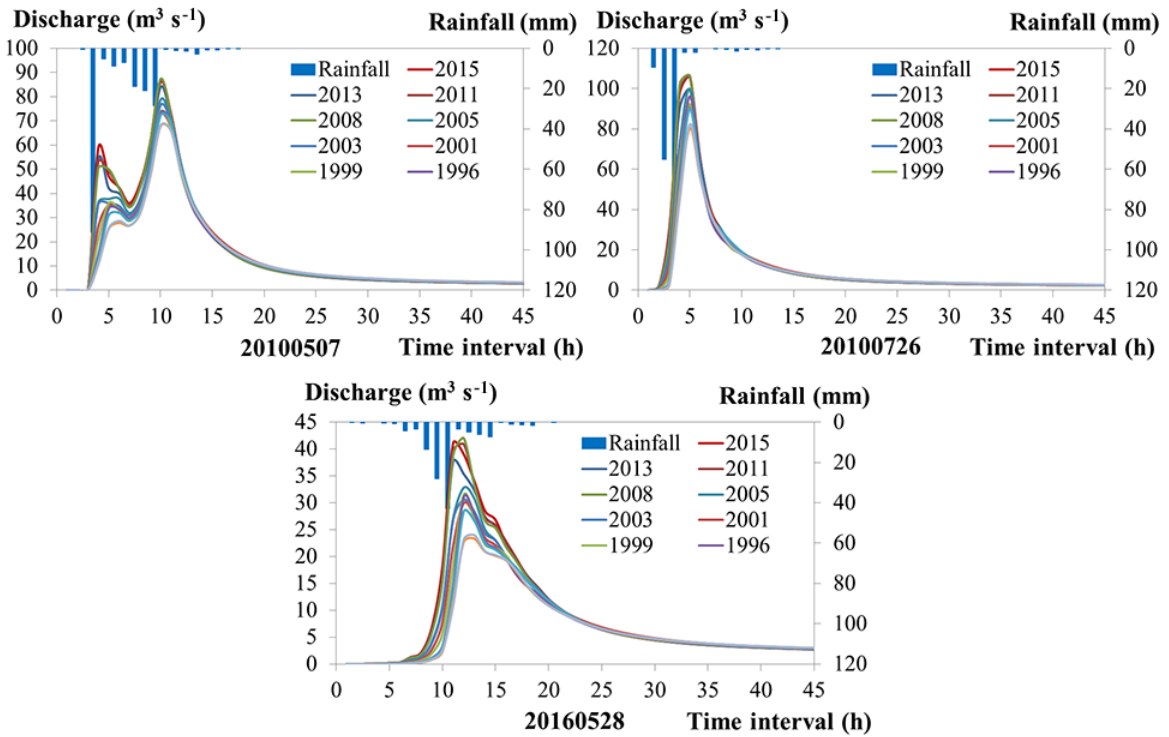

Figure 6.3 of the simulated flood hydrographs.

\section{Results and discussion}

The flood events were simulated by using the model set up in this paper, the input is the precipitation collected in this paper. 3 floods have been simulated, and the simulated flood hydrographs are shown in Fig. 6. Runoff coefficients and peak flows for each storms were calculated as shown in Tables 1 and 2 . The maximum runoff coefficient is 0.745 , the minimum runoff coefficient is 0.461 , and the averaged runoff coefficient of all the 3 storms is 0.626 . The urbanization has a significant influence on the flood characteristics of the Shigu creek. Compared with 1987, the average peak flow of 2015 increased by $19.47 \mathrm{~m}^{3} \mathrm{~s}^{-1}(42 \%)$, while the average runoff coefficient increased by $0.135(24.9 \%)$. With the increasing of the urbanization rate, the runoff coefficient and the peak flow have been increasing sharply.

It can be seen that the results are in line with our expectations. The impact of urbanization on flood response is significant. In the process of urbanization, the LUCs have changed greatly. Therefore, the LUC-related parameters and soil-related parameters in the model should be different during the study period. However, for lacking of observed discharge, the parameters cannot be optimized. As a result, in the course of the follow-up study, it is necessary to give comprehensive analysis of parameter optimization in urban area without observed discharge.

\section{Conclusion}

Results in this study shows that the urbanization of Shigu creek is very rapid, and this change has a significant impact on the flood characteristics of the Shigu creek. Compared with 1987, the average peak flow of 2015 increased by
$19.47 \mathrm{~m}^{3} \mathrm{~s}^{-1}(42 \%)$, while the average runoff coefficient increased by 0.135 (24.9\%). This will provide sound input for flood planners and managers in planning and managing the flood of Shigu creek.

Data availability. In this study, the DEM was downloaded from the Shuttle Radar Topography Mission database website (http:// srtm.csi.cgiar.org), and the soil type was downloaded from FAO soil type dataset (http://www.isric.org). The LUC types were extracted from the whole Dongguan City LUC dataset that was prepared by Chen et al. (2017a). For which, the raw data is not put in an open access dataset, but available by writing to the contacting author by email at eescyb@mail.sysu.edu.cn. The hydrological data was provided by the department of water resources of Dongguan City inclusively for this study, and is not available for the public.

Competing interests. The authors declare that they have no conflict of interest.

Special issue statement. This article is part of the special issue "Innovative water resources management - understanding and balancing interactions between humankind and nature". It is a result of the 8th International Water Resources Management Conference of ICWRS, Beijing, China, 13-15 June 2018.

Acknowledgements. This study is supported by the National Science \& Technology Pillar Program during the Twelfth Fiveyear Plan Period (funding no. 2015BAK11B02), the Science and Technology Program of Guangdong Province (funding no. 2014A050503031), and the National Natural Science Foundation of China (NSFC) (funding no. 51379222). 
Edited by: Wenchao Sun

Reviewed by: two anonymous referees

\section{References}

Abbott, M. B., Bathurst, J. C., Cunge, J. A., O’Connell, P. E., and Rasmussen, J.: An introduction to the European Hydrological System - Systeme Hydrologique Europeen, "SHE”, 1: History and philosophy of a physically-based, distributed modelling system, J. Hydrol., 87, 45-59, 1986.

Arya, L. M. and Paris, J. F.: A physioempirical model to predict the soil moisture characteristic from particle-size distribution and bulk density data, Soil Sci. Soc. Am. J., 45, 1023-1030, 1981.

Chen, Y.: Liuxihe Model, Beijing, Science Press, 198 pp., 2009.

Chen, Y. and Dong, Y.: Design and development of Liuxihe model cloud, Proceeding of the 2013 annual meeting of the Chinese Society of Hydraulic Engineering, 1231-1237, 2013.

Chen, Y., Ren, Q., Huang, F., Xu, H., and Cluckie, I.: Liuxihe Model and Its Modeling to River Basin Flood, J. Hydrol. Eng., 16, 3350, 2010.

Chen, Y., Dong, Y., and Zhang, P.: Study on the method of flood forecasting of small and medium sized catchment, Proceeding of the 2013 annual meeting of the Chinese Society of Hydraulic Engineering, 1001-1008, 2013.

Chen, Y., Li, J., and $\mathrm{Xu}, \mathrm{H} .:$ Improving flood forecasting capability of physically based distributed hydrological models by parameter optimization, Hydrol. Earth Syst. Sci., 20, 375-392, https://doi.org/10.5194/hess-20-375-2016, 2016.

Chen, Y., Zhang, T., Dou, P., Dong, L., and Chen, H.: Error Sources and Post Processing Method for Land Use/cover Change Estimation of Dongguan City - based on Landsat Remote Sensing Imagery with SVM, Remote Sensing Technology and Application, 32, 893-903, 2017a.
Chen, Y., Li, J., Wang, H., Qin, J., and Dong, L.: Largewatershed flood forecasting with high-resolution distributed hydrological model, Hydrol. Earth Syst. Sci., 21, 735-749, https://doi.org/10.5194/hess-21-735-2017, 2017 b.

Huang, J., Dong, L., Chen, Y., Wang, H., and Chen, L.: Liuxihe Model-based study on inflow flood forecasting model of Lechangxia Reservoir, Water Resources and Hydropower Engineering, 48, 1-7, 2017.

Jenson, K. and Domingue, O.: Extracting Topographic Structure from Digital Elevation Data for Geographic Information System Analysis, Photogramm. Eng. Rem. S., 54, 1593-1600, 1988.

Li, J., Chen, Y., Wang, H., Qin, J., Li, J., and Chiao, S.: Extending flood forecasting lead time in a large watershed by coupling WRF QPF with a distributed hydrological model, Hydrol. Earth Syst. Sci., 21, 1279-1294, https://doi.org/10.5194/hess-21-1279-2017, 2017.

Liang, X., Lettenmaier, D. P., Wood, E. F., and Burges, S. J.: A simple hydrologically based model of land surface water and energy fluxes for general circulation models, J. Geophys. Res., 99, 14415-14428, 1994.

Liao, Z., Chen, Y., Xu, H., and He, J.: Study of Liuxihe Model for flood and rainfall forecast of Tiantoushui Watershed, Yangtze River, 43, 12-16, 2012.

Strahler, A. N.: Quantitative Analysis of watershed Geomorphology, T. Am. Geophys. Un., 8, 913-920, 1957.

USDA: National engineering handbook, section 4, hydrology, USDA, Soil Conservation Service, US Government Printing Office, Washington, DC, 1972.

Zhao, R. J.: Flood Forecasting Method for Humid Regions of China, East China College of Hydraulic Engineering, Nanjing, China, 1977. 